\section{Range Condition Classification of Bunchgrass Range at the Manitou Experimental Forest in Colorado}

\section{W. M. JOHNSON AND ELBERT H. REID}

Range Conservationists, Rocky Mountain Forest and Range Experiment Station, Forest Service, U. S. Department of Agriculture, Fort Collins, Colorado 1

This paper indicates a method of judging range condition of grassland areas in the ponderosa pine forest of the Colorado Front Range based on relative herbage production of desirable forage species.

The loop method of Parker (1951) is now widely used in range management. Data obtained by the method include measurements of vegetation (cover index, composition, and vigor) and soils and erosion (bare ground and litter). Vigor is represented by leaf-height measurements of the major forage species. Guides for using these data for estimating range condition and trend in range condition on many plant types have been developed. However,

1 Central headquarters maintained in cooperation with Colorado State University, Fort Collins, Colorado. improvement of these range condition guides is desirable.

At Manitou Experimental Forest near Woodland Park, Colorado, six experimental pastures of ponderosa pine (Pinus ponderosa)-bunchgrass range were grazed at different levels from 1942 until 1959. Because a wide range of conditions developed, loop-method data from these pastures were analyzed to determine which measurement would give the best index to range conditions, and what the weightings of each should be.

In 1954, 320 permanent loop transects were measured in the experimental pastures. Herbage yields were obtained by clipping plots adjacent to 26 of these transects located in the grassland type. In 1955, herbage yields and height growth of leaves of moun-

2 Botanical names of plants appear later in a tabulation. tain muhly ${ }^{2}$ were obtained on 76 transects adjacent to loopmethod transects in the grassland type. Then, to test the procedure developed from the 1955 data, an entirely new set of 24 transects were measured and related herbage production data taken in 1959. Four transects were measured in the grassland type in each pasture.

\section{Conditions Sampled}

The range covered by these studies extends from what is believed to be the best condition obtainable for this area to conditions where desirable plants have been virtually eliminated, and replaced by stands dominated by fringed sagebrush and blue grama (Figure 1). Pinebunchgrass ranges can deteriorate further, but such conditions were not available for study.

Herbage production of desirable forage plants on the transect areas varied from 50 pounds per acre to 989 pounds per acre in 1954, and from 15 to 631 pounds per acre in 1955. Positive observations on desirable plants, hereafter called hits ${ }^{3}$, varied from 0 to 40 per 100 observations.

3 A "hit" as used here is an observation of a species in a three-quarterinch loop as used in the loop method described by Parker (1951). 

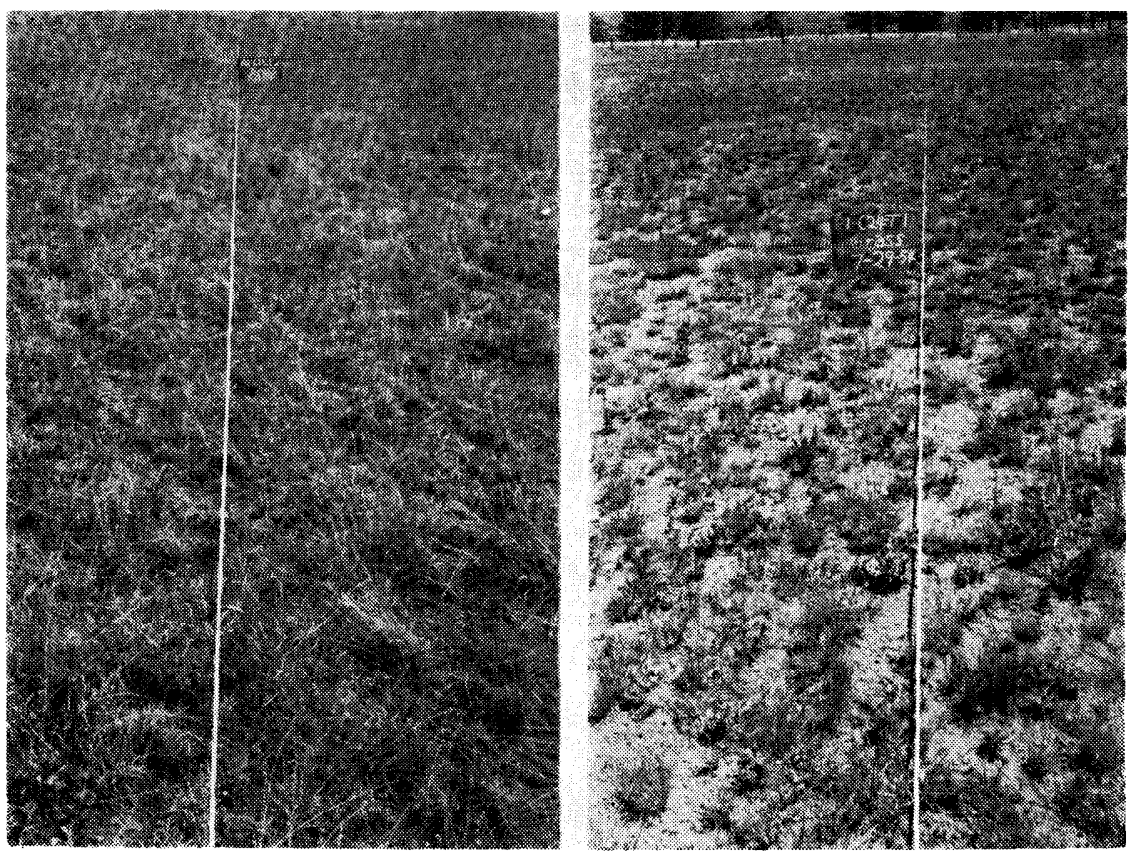

Figure 1. Left: The best condition sampled in the pine-bunchgrass type at the Manitou Experimental Forest. Herbage production of desirable forage plants was 616 pounds per acre in 1954. Right: The poorest condition sampled in the pinebunchgrass type at the Manitou Experimental Forest. Herbage production of desirable forage plants was 50 pounds per acre in 1954.

\section{Analysis Procedure}

The analysis was based on the assumption that high production of herbage by the desirable forage plants is the primary goal of range management. Therefore, a high production by desirable plants was defined as excellent condition and a low production as poor condition.

Cover measurement of desirable plants is a relatively consistent source of data, because most species are long-lived perennial grasses. Cover measurements of these plants differ with range conditions: desirable plants are sparsest on range in poor condition, as defined, and most abundant on range in excellent condition. Likewise, cover of desirable plants increases or decreases with improvement or deterioration of the range.

Production is related to plant height. Also, Short and Woolfolk (1956), Johnson (1953), and others, have shown that plant height growth is related to the intensity of grazing the plants have received over a period of years. On heavily grazed ranges, plants of the same species are shorter than on ranges lightly grazed.

These observations, together with the assumption made regarding the definition of range condition, indicated the possibility of correlating vegetative composition, cover index, and vigor with yield of desirable forage species as a method of classifying range conditions.

None of the measurements related to soils and erosion (bare soil, erosion pavement, litter) were considered in the premise. It was assumed, however, that these measurements also were indirectly related to the ultimate goal of management. Seldom would a range with a high production of desirable forage plants, in relation to maximum production for the site, have appreciable accelerated erosion. If such a condition did occur, it would probably be the result of factors other than those related to grazing by livestock.
The basic objective of the analysis was, therefore, to determine if plant composition, cover index, vigor, litter, and bare soil were individually or collectively related to herbage production of desirable forage plants.

\section{Classification of Vegetation}

Important species in the type were grouped into "Desirable," "Intermediate," and "Least Desirable" plants. This grouping was based on a combination of ecological and forage values. For the most part, the desirable group includes those species that are present in the ecological climax, that are of major importance in herbage production, and that are highly palatable to cattle. The intermediate group includes species of lower palatability and lesser abundance that occur in the ecological climax, and species of fair palatability that increase as the desirable group decreases under heavy grazing. The least desirable group includes those species that are normally unpalatable or low in palatability but sometimes become dominant as the range deteriorates. Species encountered are grouped as follows:

Botanical name Common name Desirable

Agropyron smithii

(Bluestem wheatgrass)

Agropyron subsecundum

(Bearded wheatgrass)

Androprogon scoparius

(Little bluestem)

Astragalus goniatus

(Nickleaf milkvetch)

Carex heliophila

Chrysopsis resinolens

(Sun sedge)

(Goldenaster)

Danthonia parryi

(Parry danthonia)

Festuca arizonica

(Arizona fescue)

Muhlenbergia montana

(Mountain muhly)

Stipa comata

(Needle and thread)

Vicia americana

(American vetch)

Intermediate

Achillea lanulosa

(Western yarrow) 
Blepharoneuron tricholepis (Pine dropseed)

Bouteloua gracilis

(Blue grama)

Chenopodium leptophyllum

(Slimleaf goosefoot)

Erigeron canadensis

(Horseweed fleabane)

Geranium fremontii

(Fremont geranium)

Koeleria cristata

(Prairie junegrass)

Poa pratensis

(Kentucky bluegrass)

Potentilla anserina

(Silverweed cinquefoil)

Potentilla gracilis

(Northwest cinquefoil)

Senecio spp.

Sitanion hystrix

(Groundsels)

(Bottlebrush squirrcltail)

Thermopsis montana

(Mountain thermopsis)

Least Desirable

Antennaria rosea

Arctostaphylos uva-ursi

(Rose pussytoes)

(Bearberry)

Artemisia frigida

(Fringed sagebrush)

Chrysopsis villosa

(Hairy goldaster)

Erigeron flagellaris

(Trailing fleabane)

Muhlenbergia richardsonis

(Mat muhly)

Oxytropis lamberti

(Lambert crazyweed)

Schedonnardus paniculatus

(Tumblegrass)

Sporobolus cryptandrus

(Sand dropseed)

Stipa robusta

Taraxacum officinale

(Sleepygrass)

(Common dandelion)

\section{Analysis of Data}

The 1954 data were analyzed to determine the relation of total production of desirable plus intermediate plants to (1) hits on total plant cover, (2) hits on both desirable and intermediate plants, (3) hits on desirable plants, and (4) hits on intermediate plants. The relationships were not significant or, if significant, were not strong enough to warrant further investigation. Cover measurement (hits) of desirable plants, however, was related to herbage yield of desirable plants.

The correlation coefficient be- tween the estimated herbage yield of desirable plants (Y) and hits on desirable plants (X) was $r=0.69$. The regression equation was $\mathrm{Y}=1.47 \mathrm{X}+16.35$, significant at the 5 percent level. Similarly, the regression equation for the 1955 data was $\mathrm{Y}=1.21 \mathrm{X}+$ 2.97 , the regression coefficient being comparable to that of 1954 .

Multiple regression analysis was made with the 1955 yields of desirable herbage in pounds per acre as the dependent variable (E) and the number of hits on desirable plants $\left(\mathrm{X}_{1}\right)$ and average leaf height of mountain muhly in inches $\left(\mathrm{X}_{2}\right)$ as the independent variables. This regression was highly significant with a correlation coefficient of $R=$ 0.89 . The regression equation was $\mathrm{E}=8.77 \mathrm{X}_{1}+61.63 \mathrm{X}_{2}$ 134.63.

Plant height is related to weather as well as past intensity of grazing. Five years of record at the Manitou Experimental Forest show height growth of mountain muhly to be closely related to rainfall $(r=0.92)$. Since these data were obtained from three exclosures that had not been grazed since 1939 , the plants were assumed to be in maximum vigor, and variations in height represented changes due principally to the amount of rainfall.

Plant height growth cannot be used directly as a measure of range condition due to weather because it varies. This variation in height growth, however, is found in plants of both poor and

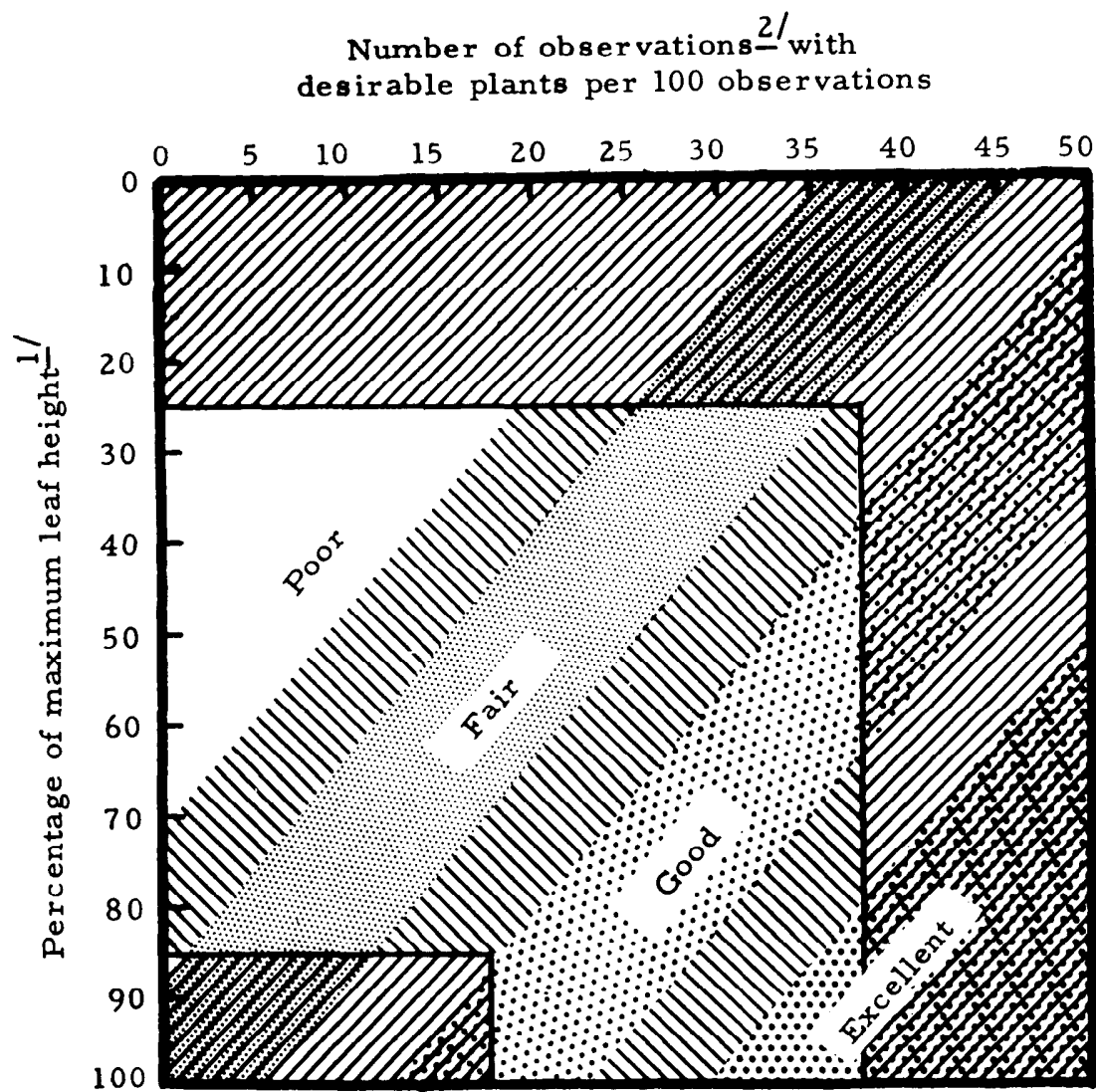

$\frac{1}{2} /$ Mountain muhly (Muhlenbergia montana)
/ Three-fourths inch loop

DIJ Transition VIJ Extrapolation of data

Figure 2. Proposed chart for determining range condition classification for grassland openings in ponderosa pine ranges, Front Range of the Rocky Mountains. (Transition band between classes represents the standard error of estimate.) 
good vigor. Plants with poor vigor that produce short growth in a year of low rainfall would still be proportionately poor in vigor and produce short growth in a year of high rainfall. This hypothesis has not been field tested but is supported by general observations.

The height variable in the regression equation was, therefore, converted to percentage of largest recorded height on the transect measured for the year 1955. This resulted in the regression $\mathrm{E}=8.77 \mathrm{X}_{1}+3.61 \mathrm{X}_{2}-134.63$, where $X_{1}$ is hits on the desirable plants and $X_{2}$ is the average height of mountain muhly on the transect expressed as a percentage of the maximum recorded height that year. Height growth ranged from 31 to 100 percent of maximum height growth.

\section{Suggested Range Condition Classes}

If it is true that the production of desirable plants reflects differences in range condition as influenced by the grazing of livestock, then an approach to establishing boundaries for condition classes is to arbitrarily divide production into classes. The number of hits of desirable forage plants and percent of maximum height growth of leaves of mountain muhly that represent these class boundaries can be determined through the use of the established regression. Condition of a transect could be classified by determining the number of hits on desirable forage plants and measuring leaf height as a percentage of the maximum leaf height of protected plants.

The data for 1955 from the Manitou experimental areas have been used as an example of this procedure. Production ranged from 0 to about 600 pounds per acre. This range in production was divided equally into four condition classes called excellent (450 pounds per acre or more), good (300 to 450 pounds), fair (150 to 300 pounds), and poor (less than 150 pounds per acre). The calculated production data from the regression were determined as shown in Table 1.

Once the condition class limits have been established to form a classification chart as shown in Figure 2, the original levels of herbage production are no longer important.

Other measurements taken by the loop method were related to

Table 1. Computed production of desirable herbage in relation to number of hits on desirable species and height of mountain muhly.

\begin{tabular}{|c|c|c|c|c|c|c|c|c|c|c|}
\hline \multirow{2}{*}{$\begin{array}{l}\text { Percentage of } \\
\text { maximum } \\
\text { height of } \\
\text { mountain } \\
\text { muhly }\end{array}$} & \multicolumn{10}{|c|}{ Number of hits on desirable species } \\
\hline & 5 & 10 & 15 & 20 & 25 & 30 & 35 & 40 & 45 & 50 \\
\hline & - & 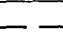 & - & $-(\mathrm{F}$ & unds & er ac & e) - & -- & -- & $-\ldots$ \\
\hline 10 & & & 33 & 77 & 121 & 165 & 208 & 252 & 296 & 340 \\
\hline 20 & & 25 & 69 & 113 & 157 & 201 & 245 & 288 & 332 & 376 \\
\hline 30 & 18 & 61 & 105 & 149 & 193 & 237 & 281 & 324 & 368 & 412 \\
\hline 40 & 54 & 97 & 141 & 185 & 229 & 273 & 317 & 361 & 404 & 448 \\
\hline 50 & 90 & 134 & 177 & 221 & 265 & 309 & 353 & 397 & 441 & 484 \\
\hline 60 & 126 & 170 & 214 & 257 & 301 & 345 & 389 & 433 & 477 & 520 \\
\hline 70 & 162 & 206 & 250 & 293 & 337 & 381 & 425 & 469 & 513 & 557 \\
\hline 80 & 198 & 242 & 286 & 330 & 373 & 417 & 461 & 505 & 549 & 593 \\
\hline 90 & 234 & 278 & 322 & 366 & 410 & 453 & 497 & 541 & 585 & 629 \\
\hline 100 & 270 & 314 & 358 & 402 & 446 & 489 & 533 & 577 & 621 & 665 \\
\hline
\end{tabular}

Table 2. Relation of measurements on transects to range condition classification ${ }^{1}$

\begin{tabular}{|c|c|c|c|c|c|}
\hline \multicolumn{2}{|c|}{ Factor measured } & Excellent & Good & Fair & Poor \\
\hline & & \multicolumn{4}{|c|}{ Number of hits per transect } \\
\hline \multirow[t]{3}{*}{ Bare soil } & Average & 21 & 32 & 35 & 41 \\
\hline & Maximum & 34 & 44 & 62 & 62 \\
\hline & Minimum & 2 & 17 & 17 & 11 \\
\hline \multirow{3}{*}{$\begin{array}{l}\text { Total ground } \\
\text { cover }\end{array}$} & Average & 79 & 68 & 65 & 59 \\
\hline & Maximum & 98 & 83 & 83 & 89 \\
\hline & Minimum & 65 & 56 & 38 & 38 \\
\hline \multirow[t]{3}{*}{ Litter } & Average & 36 & 34 & 30 & 25 \\
\hline & Maximum & 56 & 53 & 58 & 48 \\
\hline & Minimum & 24 & 18 & 6 & 10 \\
\hline \multirow[t]{3}{*}{ Plant cover } & Average & 43 & 34 & 35 & 34 \\
\hline & Maximum & 50 & 43 & 55 & 57 \\
\hline & Minimum & 40 & 24 & 21 & 15 \\
\hline \multirow{3}{*}{$\begin{array}{l}\text { Desirable plus } \\
\text { intermediate } \\
\text { plants }\end{array}$} & Average & 40 & 32 & 31 & 29 \\
\hline & Maximum & 45 & 39 & 47 & 52 \\
\hline & Minimum & 38 & 23 & 16 & 0 \\
\hline \multirow[t]{3}{*}{ Desirable plants } & Average & 36 & 27 & 15 & 7 \\
\hline & Maximum & 40 & 33 & 28 & 15 \\
\hline & Minimum & 33 & 18 & 7 & 0 \\
\hline \multirow{3}{*}{$\begin{array}{l}\text { Intermediate } \\
\text { plants }\end{array}$} & Average & 4 & 6 & 16 & 22 \\
\hline & Maximum & 9 & 10 & 35 & 49 \\
\hline & Minimum & 0 & 1 & 1 & 0 \\
\hline \multirow{3}{*}{$\begin{array}{l}\text { Least desirable } \\
\text { plants }\end{array}$} & Average & 2 & 2 & 4 & 5 \\
\hline & Maximum & 5 & 6 & 8 & 16 \\
\hline & Minimum & 1 & 0 & 1 & 0 \\
\hline \multirow{3}{*}{$\begin{array}{l}\text { Leaf height of } \\
\text { mountain } \\
\text { muhly }\end{array}$} & Average & 5.25 & 4.07 & 3.25 & 2.65 \\
\hline & Maximum & 5.83 & 5.08 & 4.25 & 3.50 \\
\hline & Minimum & 4.42 & 3.33 & 2.00 & 1.83 \\
\hline
\end{tabular}

1Based on seventy six 100-foot loop transects. 
Table 3. Average condition ratings of the four transects in each pasture by the two rating procedures.

Pasture Pasture treatment for No. previous 17 years

Condition rating

$\begin{array}{llll}1 & \text { Heavy grazing } & \text { Fair } & \text { Fair } \\ 2 & \text { Light grazing } & \text { Good to excellent } & \text { Excellent } \\ 3 & \text { Moderate grazing } & \text { Fair to good } & \text { Good } \\ 4 & \text { Heavy grazing } & \text { Poor to fair } & \text { Poor } \\ 5 & \text { Light grazing } & \text { Variable } & \text { Variable } \\ 6 & \text { Moderate grazing } & \text { Good } & \text { Fair }\end{array}$

1 Transects varied from poor to excellent due to poor distribution of utilization in the pasture, but all transects were rated the same by both methods.

the range condition classes as determined from the chart. Table 2 shows the relationships found for total ground cover, plant cover, litter, and other measurements considered. It will be noted for example, that the average number of hits on bare soil was lowest for ranges in excellent condition, increased progressively for ranges in good and fair condition, and was greatest for poor condition, a definite and logical trend.

\section{Test of Suggested Method}

The classification chart in Figure 2 was tested to determine how closely condition ratings determined from the chart, based on 1955 data, would compare with condition classification based on relative production in 1959 (Table 3).

Of the 24 transects tested, 16 were rated the same by both methods. Two were within the standard deviation of the same class on Figure 2, but were closer to a higher or lower class and would not have been rated the same by both methods. Six transects differed by one condition class.

Range condition classifications are subject to error of interpretation. Whether this method is better or poorer than those in use may be a matter of personal opinion or policy. However, this procedure does offer a method with a factual background for which the reliability can be checked.

\section{Summary}

A method of determining range condition using factors measured by the loop method was evaluated on ponderosa pine-bunchgrass range in Colorado. Range condition was classified by the relative production of desirable plants, desirability being based both on ecological status and forage values.
A good relationship was found between weight of herbage produced by desirable forage plants, and the percent cover of desirable plants and leaf height of mountain muhly, an important species on the study area. The regression equation for the vegetation and conditions of the study was $\mathrm{E}=8.77 \mathrm{X}_{1}+3.61 \mathrm{X}_{2}$ - 134.63, where $E=$ estimated yield, $\mathrm{X}_{1}=$ cover measurement of desirable species, and $\mathrm{X}_{2}=$ maximum leaf height of mountain muhly expressed as a percentage of the leaf height of the muhly on a nearby ungrazed area. A chart, developed from the formula, is presented for estimating range condition class of grassland openings in the ponderosa pine range at the Manitou Experimental Forest. The procedure is proposed as a method that will have a factual background and for which the reliability can be determined.

\section{LITERATURE CITED}

Johnson, W. M. 1953. Effect of grazing intensity upon vegetation and cattle gains on ponderosa pinebunchgrass ranges of the Front Range of Colorado. U. S. Dept. Agr. Cir. 929. 36 pp.

PARKer, KenNeth W. 1951. A method for measuring trend in range condition on National Forest ranges. U. S. Forest Service, 26 pp., illus., mimeo., Washington, D. C.

Short, L. R. AND E. J. WoOlfolk. 1956. Plant vigor as a criterion of range condition. Jour. Range Mangt. 9:66-69.

\section{CALL FOR PAPERS}

\section{ANNUAL SOCIETY CONVENTION}

Anyone wishing to present a paper at the eighteenth annual convention of The American Society of Range Management, February, 1965, in Las Vegas, Nevada, should submit a title and short abstract to the Program Committee. Chairman John D. Freeman, Box 1589, Prescott, Arizona, urges papers to be submitted early to allow time for committee review and screening. Deadline is July 15.

The theme of the convention will be "The Rancher-The Key to Range Management." Papers are especially desired that point up the theme. Emphasis this year is to interest ranchers to attend and to appear on the program.

Papers should be carefully developed as to length. (Time for presentation will be strictly controlled). Time limits of 20 or 30 minutes each will be set for each paper, including discussion period. 